\title{
Case of extensive necrosis of the oesophageal mucosa following hypothermia
}

\author{
J. L. BRENNAN \\ From the Central Histological Laboratory, Whittington Hospital, London
}

SYNOPSIS A case of necrosis of the oesophageal mucosa following hypothermia in a man of 83 is described, and the histological findings are compared with those of similar cases in the records of the Central Histological Laboratory. The condition is discussed in the light of similar lesions occurring in cases of hypothermia reported by other authors.

Necrosis of the oesophageal mucosa is an uncommon condition to which very few references can be found. It usually occurs as a terminal event in elderly subjects suffering from a wide variety of conditions, among which may be mentioned cerebrovascular accidents, carcinomatosis, chronic glomerulonephritis, or chronic infections.

\section{CASE REPORT}

S. S., aged 84 , was admitted to the Department of Neurosurgery in the Highgate Wing, Whittington Hospital, on 17 November 1965. He had been transferred from the West Middlesex Hospital where he had been under investigation for gradual mental deterioration. Two months before transfer there was a history of head injury with a short period of unconsciousness, $\mathrm{He}$ was found to have bradycardia and a rectal temperature of $80^{\circ} \mathrm{F}$. and was referred to the Department of Neurosurgery for exclusion of a subdural haematoma.

Treatment with hydrocortisone $(100 \mathrm{mg}$. six hourly for 24 hours) at the first hospital was followed by a rise in temperature to $89^{\circ} \mathrm{F}$. When examined on the day of admission he was found to be conscious but mute and incontinent of both urine and faeces. Reflexes were brisk in both arms, but the knee and ankle jerks were absent in both lower limbs. The thyroid was palpable and the skin was dry. The rectal temperature was $88.8^{\circ} \mathrm{F}$., pulse rate $48 / \mathrm{min}$., and blood pressure $160 / 90 \mathrm{~mm}$. $\mathrm{Hg}$.

A full blood examination gave $\mathrm{Hb} 93 \%(13.8 \mathrm{~g}$.); white cells $15,800 / \mathrm{c} . \mathrm{mm}$. with a polymorphonuclear leucocytosis; E.S.R. $19 \mathrm{~mm}$./one hour; serum sodium $144 \mathrm{mEq}$./1., serum potassium $4 \cdot 2 \mathrm{mEq}$./1., serum bicarbonate $19 \mathrm{mEq}$./1.; blood urea $132 \mathrm{mg}$./100 ml.; serum cholesterol $162 \mathrm{mg} . / 100 \mathrm{ml}$.

Liver function tests were within normal limits.

Protein-bound iodine was $2.8 \mu \mathrm{g}$. $/ 100 \mathrm{ml}$.

On 18 November, the cerebrospinal fluid pressure was normal. A sample of fluid was bloodstained containing

Received for publication 28 February 1967.
9 white cells and about 6,200 red cells/c. mm. and protein $140 / \mathrm{mg} . / 100 \mathrm{ml}$.

Hydrocortisone was continued in the same dosage and at $8 \mathrm{p} . \mathrm{m}$. on the day of admission bilateral postparietal burr holes were made. No haematoma or other abnormality was found.

During the night of 18 to 19 November he vomited about $500 \mathrm{ml}$. 'coffee ground' material, only weakly positive for blood, and an approximately equal volume was aspirated by Ryle's tube two hours later. He died at 6 a.m. on 19 November.

\section{NECROPSY}

EXTERNAL The body was that of a well-nourished old man with dry, scaly, slightly yellow skin.

INTERNAL There was a little discoloration of the arachnoid over the right temporo-parietal region and a little fresh clot, about $10 \mathrm{ml}$., under the dura in the same region. On section the brain appeared normal with no lacerations or haemorrhage throughout its substance. The thyroid was macroscopically normal. The most striking finding was a black discoloration of the mucosa of the oesophagus (Fig. 1) affecting roughly the lower three-quarters of the organ and ending sharply at the oesophagogastro junction. The stomach contained 'coffee ground' material but was otherwise normal, showing no ulceration or necrosis of its mucosa. The intestines were normal throughout and the liver was pale. The kidneys showed senile atherosclerotic change.

Microscopically the changes in the arteries, kidneys, and skin were consistent with those expected in a subject of his age and were not very marked.

The oesophagus (Fig. 2) showed a necrosis involving the mucosa and part of the submucosa and under this an inflammatory reaction with oedema 


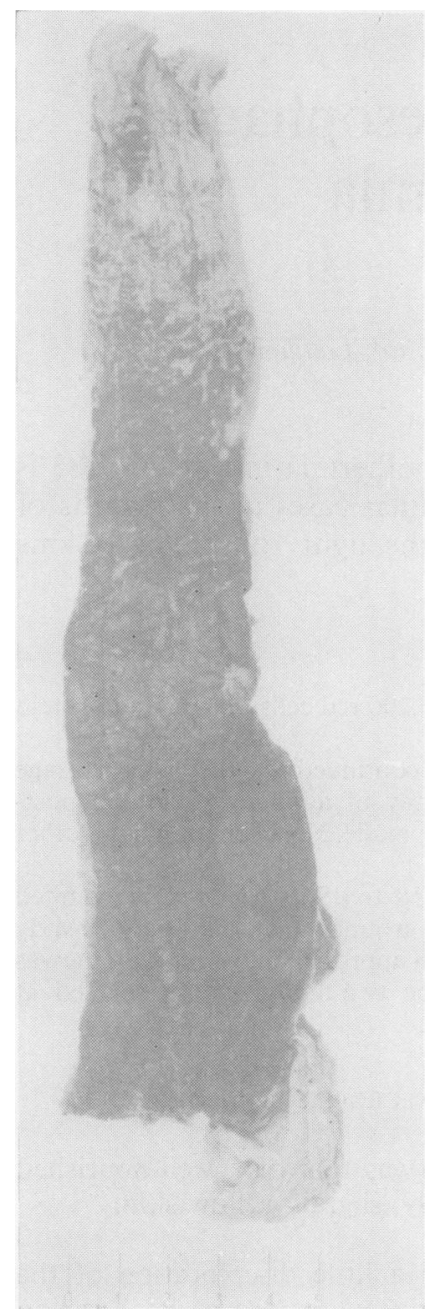

FIG. 1.

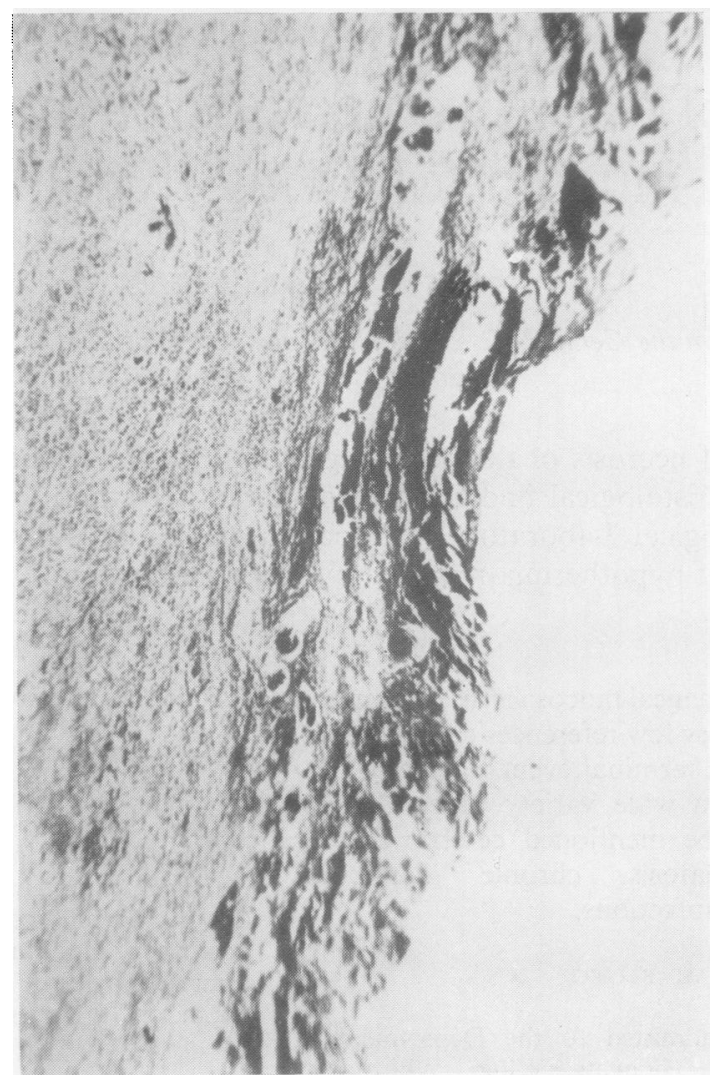

FIG. 2.

FIG. 1. Gross appearance of the oesophagus.

FIG. 2. Photomicrograph of the oesophagus $\times 90$ to show necrosis of the mucosa and part of the submucosa with intense inflammatory reaction in the underlying tissue. and a heavy polymorph exudate. As in the gross appearance there was a sharp transition to normal at the oesophago-gastric junction.

The thyroid appeared normal and active with one small area of colloidal hypertrophy.

\section{RECORDED CASES}

In the absence of any cerebral lesion death was ascribed to hypothermia complicated by acute necrotic oesophagitis. There was no history of a suicidal attempt using a corrosive liquid, the patient having been under supervision for several days before his death, and the mouth, tongue, pharynx, and stomach were completely free from lesions. A search for similar cases was made in the records of the Central Histological Laboratory and 18 cases classified under 'necrosis of oesophagus' were found in the period 1933-65. These were then subdivided into two groups: group 1 ( 7 cases) in which the oesophageal condition appeared as a terminal event at the end of a general illness, as in the case reported, and group II (11 cases) in which the necrosis appeared to be the result of a local lesion, swallowing corrosive liquids, haemorrhage, or the spread of infection from a neighbouring organ.

GROUP I The findings in this group are set out in Table I. It comprised five males and two females whose ages ranged from 50 to 79 years. Two of these patients were suffering from malignant disease, three from acute infections, and one from left ventricular failure following anaemia due to subacute nephritis. One man aged 50 (case 1) had a coronary 
TABLE I

CLINICAL AND PATHOLOGICAL FINDINGS IN GROUPS I AND II

\begin{tabular}{|c|c|c|c|c|c|c|c|}
\hline $\begin{array}{l}\text { Case } \\
\text { No. }\end{array}$ & Year & $\operatorname{Sex}$ & Age & $\begin{array}{l}\text { Clinical Features and } \\
\text { Necropsy Findings }\end{array}$ & Depth of Necrosis & State of Vessels & Type of Inflammatory Reaction \\
\hline \multicolumn{8}{|l|}{ Group 1} \\
\hline & 1937 & M. & 50 & $\begin{array}{l}\text { Meningitis and coronary } \\
\text { thrombosis }\end{array}$ & Mucosa and submucosa & Engorged & $\begin{array}{l}\text { Many polymorphs, some } \\
\text { lymphocytes }\end{array}$ \\
\hline 2 & 1943 & M. & 72 & $\begin{array}{l}\text { Carcinoma of stomach, } \\
\text { mesenteric secondaries with } \\
\text { subacute intestinal obstruction }\end{array}$ & Mucosa and submucosa & Normal & $\begin{array}{l}\text { Lymphocytes, plasma cells, and } \\
\text { fibroblasts }\end{array}$ \\
\hline 3 & 1945 & M. & 77 & $\begin{array}{l}\text { Cystitis, pyelitis, chronic } \\
\text { suppurative cholecystitis, and } \\
\text { bronchiectasis }\end{array}$ & $\begin{array}{l}\text { Focal necroses of } \\
\text { mucosa and } \\
\text { submucosa }\end{array}$ & Engorged & Mainly lymphocytic \\
\hline 4 & 1946 & M. & 68 & $\begin{array}{l}\text { Bronchopneumonia, pyelone- } \\
\text { phritis, and cystitis }\end{array}$ & Mucosa and submucosa & $\begin{array}{l}\text { Engorged and } \\
\text { thrombosed }\end{array}$ & $\begin{array}{l}\text { Weak polymorph reaction with } \\
\text { oedema }\end{array}$ \\
\hline 5 & 1949 & F. & 79 & $\begin{array}{l}\text { Subacute nephritis, anaemia, } \\
\text { and left ventricular heart failure }\end{array}$ & $\begin{array}{l}\text { Mucosa and superficial } \\
\text { part of submucosa }\end{array}$ & Normal & Occasional lymphocytes only \\
\hline 6 & 1951 & M. & 61 & $\begin{array}{l}\text { Left ventricular heart failure } \\
\text { and hypertension }\end{array}$ & $\begin{array}{l}\text { Superficial with patchy } \\
\text { necrosis of mucosa }\end{array}$ & Engorged & $\begin{array}{l}\text { Heavy lymphocytic infiltration } \\
\text { of submucosa }\end{array}$ \\
\hline 7 & 1952 & F. & 76 & $\begin{array}{l}\text { Carcinomatosis; site of primary } \\
\text { not identified }\end{array}$ & Mucosa only & Engorged & $\begin{array}{l}\text { Moderate numbers of lympho- } \\
\text { cytes, plasma cells, and histio- } \\
\text { cytes }\end{array}$ \\
\hline
\end{tabular}

\begin{tabular}{|c|c|c|c|c|c|c|c|}
\hline$\underset{1}{\text { Group II }}$ & 1934 & F. & 51 & $\begin{array}{l}\text { Suicide by swallowing strong } \\
\text { alkali }\end{array}$ & Mucosa only & Normal & $\begin{array}{l}\text { 'Mixed' with polymorphs, plasma } \\
\text { cells, and lymphocytes }\end{array}$ \\
\hline 2 & 1934 & F. & 81 & $\begin{array}{l}\text { Accidental poisoning by } \\
\text { swallowing liniment }\end{array}$ & $\begin{array}{l}\text { Almost complete loss } \\
\text { of mucosa and sub- } \\
\text { mucosa }\end{array}$ & Very engorged & $\begin{array}{l}\text { Heavy polymorph exudate with } \\
\text { marked oedema }\end{array}$ \\
\hline 3 & 1936 & F. & 28 & $\begin{array}{l}\text { Pharyngitis, laryngitis, } \\
\text { oesophagitis, and pneumonia }\end{array}$ & $\begin{array}{l}\text { Deep necrosis involving } \\
\text { innermost muscle layer }\end{array}$ & $\begin{array}{l}\text { Engorged and } \\
\text { thrombosed }\end{array}$ & $\begin{array}{l}\text { Sparse polymorphs and a few } \\
\text { lymphocytes }\end{array}$ \\
\hline 4 & 1942 & F. & 63 & $\begin{array}{l}\text { Acute oesophagitis, gastritis, and } \\
\text { duodenitis }\end{array}$ & Mucosa and submucosa & $\begin{array}{l}\text { Moderately } \\
\text { congested }\end{array}$ & $\begin{array}{l}\text { Heavy polymorph exudate with } \\
\text { oedema }\end{array}$ \\
\hline 5 & 1942 & M. & 57 & $\begin{array}{l}\text { Acute gastritis and oesophagitis } \\
\text { associated with pyogenic abscess } \\
\text { in floor of chronic gastric ulcer }\end{array}$ & Mucosa and submucosa & Very engorged & $\begin{array}{l}\text { Many polymorphs and some } \\
\text { lymphocytes }\end{array}$ \\
\hline 6 & 1943 & M. & 25 & $\begin{array}{l}\text { Haemorrhagic necrosis of } \\
\text { oesophagus associated with } \\
\text { pyaemia and agranulocytosis }\end{array}$ & Mucosa only & $\begin{array}{l}\text { Vessels empty } \\
\text { with massive } \\
\text { submucosal } \\
\text { haemorrhages }\end{array}$ & $\begin{array}{l}\text { No polymorphs, sparse chronic } \\
\text { inflammatory cells, granules of } \\
\text { inflammatory cells, granules of } \\
\text { changed blood pigment }\end{array}$ \\
\hline 7 & 1944 & F. & 17 & $\begin{array}{l}\text { Haemorrhagic diathesis termina- } \\
\text { ting aplastic anaemia }\end{array}$ & Mucosa and submucosa & Empty & $\begin{array}{l}\text { Few histiocytes and plasma } \\
\text { cells only }\end{array}$ \\
\hline 8 & 1946 & M. & 65 & Suicide by corrosive poisoning & $\begin{array}{l}\text { Superficial with patchy } \\
\text { loss of mucosa }\end{array}$ & $\begin{array}{l}\text { Vessels engorged } \\
\text { and thrombosed }\end{array}$ & $\begin{array}{l}\text { Sparse lymphocytes and plasma } \\
\text { cells only }\end{array}$ \\
\hline 9 & 1947 & M. & 54 & $\begin{array}{l}\text { Ulceration of oesophagus } \\
\text { following secondary involement } \\
\text { from syphilitic aneurysm of aorta }\end{array}$ & $\begin{array}{l}\text { Superficial involving } \\
\text { part of mucosa only }\end{array}$ & Congested & $\begin{array}{l}\text { Many lymphocytes and plasma } \\
\text { cells with heavy polymorph } \\
\text { exudate seen }\end{array}$ \\
\hline 10 & 1952 & F. & 52 & $\begin{array}{l}\text { Fibrinopurulent inflammation } \\
\text { from infection following } \\
\text { resection and anastomosis for } \\
\text { carcinoma of oesophagus }\end{array}$ & Mucosa only & Very engorged & $\begin{array}{l}\text { Mixed exudate of polymorph and } \\
\text { other inflammatory cells }\end{array}$ \\
\hline 11 & 1952 & F. & 63 & $\begin{array}{l}\text { Infection and ulceration in } \\
\text { anastomosis following total } \\
\text { gastrectomy for carcinoma of }\end{array}$ & Mucosa only & Very engorged & $\begin{array}{l}\text { 'Subacute' reaction with poly- } \\
\text { morphs predominating }\end{array}$ \\
\hline
\end{tabular}
stomach

thrombosis in addition to an infection, meningitis. The inflammatory reaction was mainly of the 'chronic' type with lymphocytes, plasma cells, and histiocytes predominating over polymorphs.

GROUP II The second group was more heterogenous (including four males and seven females) and contained three cases of corrosive poisoning, three cases of blood dyscrasia, one following spread of syphilitic infection from an aortic aneurysm and two 'surgical' cases in which necrosis followed resection of part of the oesophagus or stomach for carcinoma. The remaining two cases were of gastro- intestinal infections in which the oesophagus was involved together with other parts. The histological findings are summarized in Table II; generally the appearances were those of an acute pyogenic infection with a predominantly granulocytic exudate.

COMPARISON OF GROUPS I AND II The histological differences between the two types of oesophageal necrosis were not clear cut. Those cases in group II with necrosis from acute infection tended to show a more granulocytic response but this was not invariable. The three young patients suffering from blood conditions-granulopenia, agranulocytosis, and 
aplastic anaemia respectively-naturally showed little or no polymorph exudate. On the other hand, patients in group I, mainly aged, moribund subjects, might be expected to show a poor leucocyte response. This was so in six of the seven, but the writer's case showed a marked leucocyte response despite the age and poor vitality of the patient. Histological appearances could not, therefore, draw any clear line of demarcation between 'primary' and 'secondary' oesophageal necrosis.

\section{DISCUSSION}

Necrotic lesions of the oesophagus may be divided into two groups. The first, for want of a better term, may be called 'idiopathic' or primary where ulcerative necrotic lesions occur as a terminal event in any severe illness.

The second group, comprising all cases of 'secondary' necrosis, includes all other lesions, whether due to damage from corrosive liquids, spread of infection from adjacent organs or structures, damage to the mucosa in blood dyscrasias, or following oesophageal or gastric surgery.

The case reported in this paper is considered as an example of the first group. Corrosive poisoning was unlikely: the normal appearance of the mouth, tongue, fauces and stomach ruled it out completely. The absence of any infected lesion in the stomach, lung, or other neighbouring structure excluded spread of infection to the oesophagus. In searching for an explanation of necrosis involving nearly the whole mucosa it was first considered that the lesion was a complication of corticosteroid therapy used to combat the patient's hypothermia. This hypothesis was, however, quickly discarded since treatment with steriod drugs had been used only for a few days before death and comparison with the other cases in group I showed that oesophageal necrosis could follow any severe illness and had in fact been found long before the use of steroid compounds in therapy.

Gastrointestinal ulceration associated with severe burns (Curling, 1866) has been recognized for many years but necrotic lesions in subjects dying from exposure to cold are less well known. In Britain necropsies on such subjects are rare and when performed will usually be done by forensic pathologists at the request of the coroner. For this reason mention of such conditions is uncommon in textbooks of general pathology. In the recent edition of Taylor, Simpson (Taylor, 1965) described local necrotic lesions occurring in the stomach, oesophagus, liver and pancreas, citing original observations by Dalgaard and Mant.

Dalgaard's paper (Dalgaard, 1958) is mainly devoted to gastrointestinal ulceration following burns, but he describes one case of a 52-year-old man who fractured a femur while skiing alone and died of exposure. About 20 haemorrhagic erosions were found in the stomach. Mant (Mant, 1964) found gastric lesions in five out of six cases of accidental hypothermia in subjects with ages ranging from 5 months to 83 years. He attributed the erosions to tissue anoxia and microinfarcts due to sludging or clotting of blood in the smaller vessels. Neither of the above authors described oesophageal lesions in connexion with hypothermic states. It appears reasonable, however, to ascribe the conditions found in the case reported by the writer to the effect of hypothermia after such other causes, as intracerebral lesions, infection, and malignancy had been excluded. The blood supply of the oesophagus (Terracol and Sweet, 1958) is more easily disturbed than that of the stomach and microinfarction as envisaged by Mant could readily occur in its wall.

Dalgaard used the terms 'oesophagomalacia' and 'gastromalacia' to describe a condition of the oesophagus or stomach in which there was autolysis of the mucosa shortly before or after death, resulting in a paper-thin organ and sometimes perforation with little or no inflammatory reaction. Obviously such a condition is of some medico-legal importance since it should be considered as a concomitant of dying rather than a cause of death.

The present case is not typical of such a lesion. It seems likely that the oesophageal condition was present for at least $\mathbf{4 8}$ hours before the patient died so that there was sufficient time for an inflammatory reaction to take place.

I wish to thank Dr. J. D. B. Andrews of the West Middlesex Hospital and Mr. Ian McCaul, head of the Department of Neurosurgery, Highgate Wing, Whittington Hospital, for permission to publish this case. I would also like to thank Professor Keith Simpson for his kindness in supplying a copy of Dalgaard's paper which was not available elsewhere.

\section{REFERENCES}

Dalgaard, J. B. (1958). J. forens. Med., 5, 16.

Mant, A. K. (1964). Med. Sci. Law, 4, 44.

Taylor, A. S. (1965). Taylor's Principles and Practice of Medical Jurisprudence, 12th ed., edited by K. Simpson, vol. I, p. 326. Churchill, London.

Terracol, J., and Sweet, R. H. (1958). Diseases of the Esophagus, p. 21. Saunders. Philadelphia. 